\title{
The doors of learning ...
}

As I write this, our universities are in crisis - a crisis that has been coming since last year when the first protests about fees started. These prompted a zero fee increase for 2016, which has crippled most of our institutions of higher learning, already struggling with falling government funding. Between 1994 and 2014, the number of students in public universities more than doubled. During the same period the proportion of black students at universities increased from $52 \%$ to $81 \%$ of the student population. However, as an open letter from 1200 university academics to president Jacob Zuma and higher education minister Blade Nzimande in August this year (2016) says, this increase in student numbers has not been matched by adequate funding. ${ }^{[1]}$ In fact, every year has seen a decrease in real terms of government funding to public universities. The letter goes on to say that 'our public universities can in fact barely be called public, with national government subsidies to university budgets falling from an already low $49 \%$ in 2000 to $40 \%$ in 2012'. At the same time, employment of full-time staff has not matched increases in student numbers, potentially decreasing the quality of teaching and adding to the administrative burden on full-time academic staff. The situation in our medical schools is arguably even worse, with frozen posts in the public hospitals that provide much of our medical teaching.

The current protests are about an allowed $8 \%$ fee increase for 2017 - only for certain groups of students. The poorest will still get at least some government subsidy, including their fees paid. As I write, the University of Cape Town is closed, with no idea when it will open again. The University of the Witwatersrand is open, but if the level of violence associated with the recent protests on its campuses continues or escalates, it seems that its chances of finishing the 2016 academic year are slim. The University of KwaZulu-Natal is once again being subjected to violent protests, and the academic programme is also in serious danger. The University of Limpopo closed 2 weeks ago, and its 2016 academic programme appears to have been abandoned. Reading the comments on the social media pages of Wits and UCT is instructive. While the majority of students desperately want to finish the year, there is a vocal, persistent and often violent group who simply want to close the universities until their demand for free education is met - however long that takes, and whatever the consequences. This group of students is managing to hold our universities to ransom because of the violence of their protest action, which is not only endangering those who remain on campus but has also (including the 2015 protests) so far cost the country around ZAR600 million in damage to university property.

If the medical classes of 2016 do not graduate at the end of this year, there will be no intake of interns in 2017 and that cohort of community service doctors will also be lost. Our public health services are heavily dependent on these junior medical staff. So far, no one has been prepared to say exactly what the consequences will be, although minister of health Aaron Motsoaledi has been heard to say that the lack of interns will be disastrous. The prospect for final-year medical students is bleak - and many of them may well not manage to find the funds to repeat the year.

A 2012 estimate by Moneyweb ${ }^{[2]}$ put the cost of educating a single doctor in South Africa (SA) at ZAR250 000 a year - more than ZAR1.5 million for the whole degree. Yes, tertiary education in SA needs to be more easily accessible to those who cannot directly finance their own studies - 'free', if you like. But nothing is 'free' someone pays, somewhere. Our government's response to this crisis would be laughable if it were not so tragic. The president and the higher education minister together are leaving the universities to bear the brunt of anger that should be directed at government. Until our elected parliamentary representatives step up and take responsibility for their actions, we are likely to see the collapse of some of the finest academic institutions on the continent, and indeed in the world.

\section{Bridget Farham}

Acting Editor

ugqirha@iafrica.com

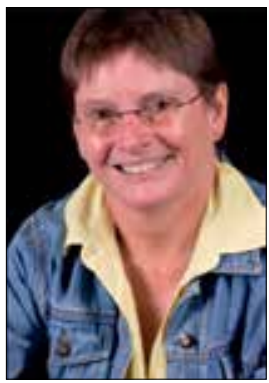

1. Govender P. More than 1200 academics plead with government to address funding crisis. Mail \& Guardian, 15 August 2016. http://mg.co.za/article/2016-08-15-00-more-than-1-200-academics-pleadwith-government-to-address-funding-crisis (accessed 11 October 2016).

2. Carte D. The cost of medical education: And why our doctors emigrate. Moneyweb, 2 November 2012. http://www.moneyweb.co.za/archive/the-cost-of-medical-eductation/ (accessed 11 October 2016).

S Afr Med J 2016;106(11):1058. DOI:10.7196/SAMJ.2016.v106i11.12102 